\title{
Eradications of invasive alien species in Europe: a review
}

\author{
Piero Genovesi \\ Chair European Section IUCN SSC Invasive Species Specialist Group, National Wildlife Institute, Via Ca' \\ Fornacetta 9, 40064 Ozzano, Emilia (BO), Italy (e-mail: infspapk@iperbole.bologna.it; fax: +39-051- \\ 796628)
}

Recevied 4 June 2003; accepted in revised form 30 March 2004

Key words: animal rights, biological invasions, control, mitigation of impacts, removal

\begin{abstract}
Eradication of alien species is a key conservation tool to mitigate the impacts caused by biologic invasions. The aim of the present paper is to review the eradications successfully completed in Europe and to discuss the main limits to a wider application of this management option in the region. On the basis of the available literature - including conference proceedings, national reports to the Bern Convention, etc. - a total of 37 eradication programmes have been recorded. Thirty-three eradications were carried out on islands and four on the mainland. The rat (Rattus spp.) has been the most common target $(n=25,67 \%)$, followed by the rabbit $(n=4)$. In many cases, these eradications determined a significant recovery of native biodiversity. Differently to other regions of the world, no eradications of alien invertebrates and marine organisms have been recorded; regarding invasive alien plants, it appears that only some very localized removals have been completed so far in Europe. The limited number of eradications carried out in Europe so far is probably due to the limited awareness of the public and the decision makers, the inadequacy of the legal framework, and the scarcity of resources. Synthetic guidelines for improving the ability of European states to respond to aliens incursions are presented.
\end{abstract}

\section{Introduction}

Eradication of alien species is globally acknowledged as a key management option for mitigating the impacts caused by biological invasions (e.g., Wittenberg and Cock 2001; Genovesi and Shine 2003). The Convention on Biological Diversity (CBD) calls for a hierarchical approach, primarily based on the prevention of unwanted introductions, but considering eradication as the best alternative when prevention fails (guiding principles adopted in 2002 with Decision VI/23). Article 11 of the Bern Convention (which has almost all European states as its members) calls parties to strictly control the introduction of invasive alien species, and the standing committee of this convention has approved many recommendations urging parties to activate eradications of intro- duced species. Also, the Global Strategy for Plant Conservation, adopted by the CBD Conference of the Parties in 2002, urges parties to eradicate some major alien species that threaten plants, plant communities and associated habitats and ecosystems.

Many invasive alien species have been eradicated worldwide, managing in this way to prevent the impacts they cause to biological diversity, economy and human well being (Simberloff 2002). In recent years, eradications have become a routine management tool especially on islands, where many introduced vertebrates have been successfully removed: for example, in New Zealand, 156 eradications have been completed (D. Veitch, pers. comm.); in northwestern Mexico, eradications have been carried out from 23 islands since 1995 (Tershy et al. 
2002); in West Australia, mammal eradications have been completed on 48 islands since 1969 (Burbridge and Morris 2002). Most of these eradications have involved vertebrates, but there are also examples of successful eradications of plants (Rejmanek and Pitcairn 2002) and invertebrates, including fruit flies from Nauru (Allwood et al. 2002) and Anopheles gambiae from over $30,000 \mathrm{kmq}$ of Brazil in the 1950s (Davis and Garcia 1989). Even marine organisms have been eradicated in some cases (when invasion was still localized) as a Mussel (Mytilopsis sp.) introduced in Cullen Bay (Australia) (Bax et al. 2002) and a sabellid polychaete (Terebrasabella heterouncinata) successfully removed from a mariculture facility in California (Galil 2002).

Successful eradications have brought very significant effects in terms of recovery of native biological diversity. Focusing on Europe, the eradication of rats from the islands of the Mediterranean has been proven to determine the recovery of many colonial nesting seabirds as the storm petrel (Hydrobates pelagicus) and the Cory's shearwater (Calonectris diomedea) (Martín et al. 2000), but also of several terrestrial bird species such as the dunnock (Prunella modularis), the wren (Troglodytes troglodytes) and the rock pipit (Anthus petrosus) (Kerbiriou et al. 2004). In an analysis of the consequences of the black rat (Rattus rattus) introduction in the Mediterranean, Martin et al. (2000) concluded that the elimination of rats from medium-sized Mediterranean islands may be particularly efficient in recovering several bird species, some of which are highly threatened.

Surprisingly, despite removal techniques having been greatly improved, Europe has a particularly solid technical and scientific background, and there are large areas (e.g., Mediterranean islands, Macaronesian archipelagos, etc.) where this management option may be very helpful in the recovery of threatened species and ecosystems - the eradication of alien species appears to be still only occasionally considered for conservation in Europe. For example, in the proceedings of a recent international conference on eradication of island invasives, there was only one European contribution reporting a failed attempt to eradicate Spartina anglica from some estuarine areas of Northern Ireland (Hammond and Cooper 2002).
In order to assess the diffusion of eradication programmes in Europe and the main limiting factors to a wider application of this management option, the present paper reviews all the known cases of eradications of alien species of plants and animals successfully completed in the region.

\section{Methods}

This review intends to cover all cases of eradications, defined as the complete and permanent removal of all wild populations of a species from a defined area by means of a time-limited campaign (Genovesi 2000; modified from Bomford and O'Brien 1995). The above definition is considered in an extended way, including the cases of removal of few individuals, because I did not want to exclude the cases when an introduced species was detected early after its arrival and immediately removed. This, in fact, is the best response to an introduction, although such a large definition may risk to create some overlap between the eradication of a few individuals (e.g., removal of a few beavers in France or of a few individuals of domestic cats from an island, both cases included in the review) and the simple capture of individuals after escape from captivity (not included in the review).

The information on eradications is particularly difficult to collect, because it is scattered, often available only in grey literature, if it is published at all (Simberloff 2002). For the present review, I firstly checked the scientific publications, focusing in particular on the proceedings of conferences and workshops held in recent years on the issue of alien species (e.g., in 1999, the Council of Europe organized in Malta the first European workshop specifically focused on the eradication of terrestrial alien species). Another important source of information has been the reports prepared by parties of the Council of Europe to the Bern Convention secretariat. In fact, as said above, the Bern Convention Standing Committee has approved several recommendations (rec. 18 (1989); rec. 45 (1995); rec. 57 (1997); rec. 61 (1997); rec. 78 (1999); rec. 77 (1999); etc) urging parties to eradicate alien species threatening native biodiversity; to respond to these recommendations, many European countries have established national reports illustrating the activi- 
ties carried out in their territories on this specific management option. In order to facilitate the collection of these national reports, the Council of Europe has also organized several meetings of experts in invasive alien species, and the proceedings of these workshops have also been extensively analysed for the review. Lastly, much information has been obtained directly by specialists, managers and NGOs.

\section{Results}

A total of 37 eradication programs successfully completed in Europe have been recorded (Table 1). These include the successful removal of the coypu and the muskrat from Great Britain, of rats, goats, rabbits and American minks from several small islands of the Macaronesia, Mediterranean, Brittany, Britain and the Baltic sea. Thirty-three eradications were carried out on islands and four on the mainland (muskrat, coypu and a small population of Indian porcupines from the British isles; the Canadian beaver from France). The rat (Rattus spp.) has been the most common target $(n=25,67 \%)$, followed by the rabbit $(n=4)$. Almost all eradications realized in Europe (apart from the muskrat and the coypu) were started for conservation purposes; in 12 cases, the programmes were co-funded by the European Union through LIFE programmes. Most eradications were carried out after the 1980s $(n=31 ; 84 \%)$, and in recent years, the number of projects is rapidly increasing.

In some cases, the eradications reported have involved very few animals (e.g., cats from Alegranza, where only two animals were killed; 12 porcupines from Devon); very likely there have been many more cases than those reported in which a few individuals that arrived at some areas were rapidly removed.

I did not record any eradication of alien invertebrates and marine organisms. Although some local eradications of invasive plants have been carried out (for example in Great Britain by Plantlife International), I did not find information on these cases on the sources I acceded for the review. Apart from a few local cases (i.e. virtual eradication of Australian swamp stonecrop Crassula helmsii from a pond in Gerrard's Cross - Buckinghamshire - by using a glyphosate-based compound over 2 years; A. Miller, unpubl. report), I think it can be said that no larger eradication of alien plants has been ever successfully carried out in Europe so far.

\section{Discussion}

The list of eradications presented here is far from being comprehensive, as I probably failed to collect information on several small scale removals of alien plants and animals. However, the general picture that comes out from this review is probably correct. In Europe, only a very limited number of eradications have been successfully completed so far, and these do not include any invertebrate, plant or marine organisms. Europe, despite its long tradition of nature conservation, its solid scientific background and the large availability of funds in respect to other geographical regions, is in this specific field of action far behind other and less developed areas of the world.

The small number of eradications carried out in Europe is due to several reasons. For example, in the attempted eradication of the grey squirrel in Italy, the failure of the programme was mainly due to the inadequate legal basis (in most European states, alien species are often automatically protected by national laws), the scarce awareness, the unclear line of authority, and the opposition of radical animal rights groups (Genovesi and Bertolino 2001; Bertolino and Genovesi 2003). In the famous case of the Caulerpa taxifolia (Meinesz 1999), a decision on whether to start an eradication or not was delayed for long, partly because of an academic controversy, partly because of the unclear repartition of roles. The removal of the rabbit from a small island of the Canary was suspended when it was almost completed, because the project ran out of funds; a re-start of the eradication has now been approved, but the suspension has totally defeated the results obtained in the first campaign, when the population was almost completely removed (Martín 2002; A. Martín, pers. comm.). Legal inadequacy and scarce resources are indicated as the major constraints to the possibility to eradicate Spartina anglica from Northern Ireland estuaries (Hammond and Cooper 2002). 
Table 1. Sources: (1) Gosling and Baker 1989; (2) J. Hughes, pers. comm.; (3) Zonfrillo 2002; (4) Smallshire and Davey 1989; (5) Macdonald et al. 2002; (6) Pascal 1999; (7) Kerbiriou et al. 2004; (8) M. Pascal, pers. comm.; (9) Rouland 1985; (10) Perfetti and Sposimo 2001; (11) Perfetti et al. 2001; (12) Oliveira 1999; (13) Pitta Groz 2002; (14) Jimenez 1994; (15) Martín 2002; (16) A. Martín, pers. comm.; (17) J.L. Rodriguez-Luengo, pers. comm.; (18) J. Mayol, pers. comm.; (19) Orueta, in preparation.

\begin{tabular}{|c|c|c|c|c|c|c|c|c|}
\hline Country & Region & Archipelago & Island & Area (ha) & Species & $\begin{array}{l}\text { Estimated } \\
\text { population } \\
\text { size }\end{array}$ & $\begin{array}{l}\text { Eradication } \\
\text { year }\end{array}$ & Source \\
\hline \multirow[t]{7}{*}{ Great Britain } & $\begin{array}{l}\text { Pertshire, } \\
\text { Sussex }\end{array}$ & & & $\sim 100,000$ & Ondatra zybethicus & & 1935 & 1 \\
\hline & Wales & & Puffin & 32 & Rattus norvegicus & & 1998 & 2 \\
\hline & Scotland & & Handa & 363 & Rattus norvegicus & & 1997 & 2 \\
\hline & Scotland & & Ailsa Craig & 104 & Rattus norvegicus & & 1990 & 2,3 \\
\hline & Wales & & Ramsey & 253 & Rattus norvegicus & & 2000 & 2 \\
\hline & West Anglia & & & & Myocastor coypus & 6000 & 1981 & 1 \\
\hline & Devon & & & & Hystrix brachyura & 12 & 1980 & 4 \\
\hline Estonia & Baltic & & Hiiumaa & $\sim 100,000$ & Mustela vison & 50 & 1998 & 5 \\
\hline \multirow{14}{*}{ France } & Brittany & Sept Ile & Rouzic & 3 & Rattus norvegicus & & 1951 & 6 \\
\hline & Brittany & Sept Ile & Bono & 22 & Rattus norvegicus & 700 & 1994 & 6 \\
\hline & Brittany & Sept Ile & aux Moines & 9 & Rattus norvegicus & 200 & 1994 & 6 \\
\hline & Brittany & Sept Ile & Plate & 5 & Rattus norvegicus & 100 & 1994 & 6 \\
\hline & Brittany & Sept Ile & aux Rats & 0 & Rattus norvegicus & 20 & 1994 & 6 \\
\hline & Brittany & Rimains & Rimains & 2 & Rattus norvegicus & 100 & 1994 & 6 \\
\hline & Brittany & Rimains & Chatellier & 1 & Rattus norvegicus & 50 & 1994 & 6 \\
\hline & Brittany & Rimains & $\begin{array}{c}\text { Rocher de } \\
\text { Cancale }\end{array}$ & 0 & Rattus norvegicus & 10 & 1994 & 6 \\
\hline & Brittany & Molène & Trielen & 15 & Rattus norvegicus & 150 & 1996 & 6,7 \\
\hline & Brittany & Molène & $\begin{array}{l}\text { Enez ar } \\
\text { C'hrizienn }\end{array}$ & 1 & Rattus norvegicus & 30 & 1996 & 6 \\
\hline & Brittany & Houat & aux Chevaux & 3 & Rattus norvegicus & & 2002 & 8 \\
\hline & Brittany & Tomé & Tomé & 30 & Rattus norvegicus & & 2002 & 8 \\
\hline & Corsica & & Lavezzi & 110 & Rattus rattus & & 2000 & 8 \\
\hline & St. Fargeau & & & & Castor canadensis & 24 & 1985 & 9 \\
\hline \multirow[t]{6}{*}{ Italy } & Tuscany & Tuscan & Legemini (1) & 10 & Rattus rattus & & 1999 & 10,11 \\
\hline & Tuscany & Tuscan & Legemini (2) & 10 & Rattus rattus & & 2000 & 10,11 \\
\hline & Tuscany & Tuscan & $\begin{array}{l}\text { Scoglio La } \\
\text { Peraiola }\end{array}$ & 10 & Rattus rattus & & 2000 & 10,11 \\
\hline & Tuscany & Tuscan & dei Topi & 10 & Rattus rattus & & 2000 & 10,11 \\
\hline & Tuscany & Tuscan & d'Ercole & 10 & Rattus rattus & & 2000 & 10,11 \\
\hline & Tuscany & Tuscan & La Scola & 2 & Rattus rattus & & 2001 & 10,11 \\
\hline \multirow[t]{2}{*}{ Portugal } & Macaronesia & Madeira & Deserta grande & 1421 & Oryctolagus cuniculus & & 1998 & 12 \\
\hline & Macaronesia & Azores & Praia Islet & 11 & Oryctolagus cuniculus & $100-200$ & 1997 & 13 \\
\hline \multirow[t]{7}{*}{ Spain } & & Columbretes & Isla Grossa & 14 & Oryctolagus cuniculus & 175 & 1993 & 14 \\
\hline & Macaronesia & Canary & Montana Clara & 130 & Oryctolagus cuniculus & 127 & 2001 & 15 \\
\hline & Macaronesia & & Lobos & 430 & Felis catus & 4 & 2001 & 16,17 \\
\hline & Macaronesia & & Alegranza & 1020 & Felis catus & 2 & 2002 & 16,17 \\
\hline & Mediterranea1 & Balearic & Dragonera & 280 & Capra hircus & & 1975 & 18 \\
\hline & Mediterranea & & Conills & 1 & Rattus rattus & $>100$ & 1999 & 18 \\
\hline & Mediterranea & Chafarines & $\begin{array}{l}\text { Ray } \\
\text { Francisco }\end{array}$ & 12 & Rattus rattus & ca. $50 /$ ha & 2000 & 19 \\
\hline
\end{tabular}

The lack of concern, awareness and public support to the removal of vertebrates seems more diffuse in Europe than in other regions of the world. Apart from the grey squirrel case in Italy, several goat eradication projects have been stopped by public opposition (e.g., in the Parco
Naturale di Portofino, Italy); public opposition is likely the main reason why only one goat eradication has been completed so far. Even in the case of the Coypu, the removal of a population recently introduced in a small lake in Sicily was strongly opposed by the local branch of the 
WWF, and never started. Also, a proposal to eradicate the hedgehog (Erinaceus europeus) from Uist (Western Islands, Scotland), where the species causes impact on several bird species by egg predation, has been rejected for the ethical opposition to the control techniques.

Another problem is the limited ability to detect new invasions early and to rapidly respond to these. Although large scale eradications are scientifically and technically challenging, the best cases of eradication are those carried out rapidly after the arrival of a new species, before it starts to spread (e.g., Rouland 1985). In Italy, we recently discovered a population of Asian squirrels ( $\mathrm{Cal}$ losciurus sp.) in Maratea, a small tourist town on the southern coast of Italy; the squirrels have probably been introduced over 30 years ago, and in this time lapse, no local or national service (forest service, game departments, etc.) managed to detect the species; only in late 2002, when the population became very abundant causing increasing problems to trees and cables, the presence was reported to the National Wildlife Institute, when it was probably too late to remove them (G. Aloise et al., in preparation).

Despite the various problems highlighted here, there are several examples of very effective actions carried out in Europe. The eradication of the coypu from West Anglia is one of the largest and the most complex eradications ever realized in the world; its success was made possible by a sciencebased planning of the removal, adequate funding and the approval of a specific legislation. The eradication of the Himalayan porcupine from Devon required ca. $€ 230,000$ for removing 12 animals only (costs actualized to year 2000), but likely prevented much more severe economic losses to crops in the long term (Smallshire and Davey 1989). The ongoing eradication of the ruddy duck (Oxyura jamaicensis) from the Palearctic, is indeed the most ambitious eradication ever planned for conservation purposes, as it requires a complex coordination and cooperation scheme among many different countries, where the main control efforts need to be concentrated in a country (Great Britain), that is not the area where the impacts are recorded (hybridization with the white headed duck, O. leucocephala, occurs in the Iberian peninsula) (Hughes et al. 1999); furthermore, the control of the ruddy duck (a beautiful ornamental duck) in Great Britain shows that it is possible to effectively address the opposition of the public, provided a solid effort and commitment by both the academic world and the non-profit organisations are made.

In conclusion, on the basis of the information on eradication summarized in the present paper, the main lesson that we can learn is that in Europe, more than elsewhere, we urgently need to revise our policies to ensure early detection and rapid response to new incursions, with an increased ability to eradicate at least the most threatening alien species. The key elements for such a revision of national policies have been recently reviewed by Genovesi and Shine (2003) and include the following:

- Promote education and public awareness programmes to engage local communities and appropriate sector groups in eradication; encourage their participation.

- Review national legislation to ensure that the legal status of alien species is compatible with mitigation measures.

- Streamline the authorization process for rapid response; consider the use of emergency orders where urgent eradication action is needed; equip competent authorities with powers to take appropriate mitigation measures.

- Establish procedures to collect, analyse and circulate information of alien species, including identification keys for different taxonomic groups.

- Set up early warning systems, focusing especially on key areas.

- Prepare contingency plans for eradicating specific taxa (e.g., plants, invertebrates, marine organisms, fresh-water organisms, fresh-water fishes, reptiles, amphibians, birds, small mammals, large mammals).

- Provide adequate funds and equipment for rapid response to new invasions and train relevant staff to use the eradication methods selected.

- Prepare and implement, providing adequate funds and support, eradication plans for some major alien species.

\section{Acknowledgements}

The information in this paper was largely provided by many colleagues and institutions. I wish to thank Nicola Baccetti, Simon Baker, Giuseppe Brundu, Lois Child, Bruno Foggi, Martin 
Harper (Plantlife International), Julian Hughes (RSPB), Juan Luis Rodriguez Luengo, Tiit Maran, Aurelio Martín, Joan Mayol, Amanda Miller, Paulo Jorge Oliveira, Jorge Orueta, Michael Pascal 'Ratator', Antonio Perfetti, Maria 'super' Pitta Groz. Special thanks to Bé Queiroz for having helped me to understand the elements of the European conservation policy.

\section{References}

Allwood AJ, Vueti ET, Leblanc L and Bull R (2002) Eradication of introduced Batrocera (Diptera: Tephritidae) in Nauru using male annihilation and protein bait application techniques. In: Veitch D and Clout $\mathrm{M}$ (eds) Turning the Tide: The Eradication of Invasive Species, pp 19-25. IUCN SSC Invasive Species Specialist Group. IUCN, Gland, Switzerland/Cambridge, UK, viii +414 pp

Bax N, Hayes K, Marshall A, Parry D and Thresher R (2002) Man-made marinas as sheltered islands for alien marine organisms: establishment and eradication of an alien invasive marine species. In: Veitch D and Clout M (eds) Turning the Tide: the Eradication of Invasive Species, pp 26-39. IUCN SSC Invasive Species Specialist Group. IUCN, Gland, Switzerland/Cambridge, UK, viii +414 pp

Bertolino S and Genovesi P (2003) Spread and attempted eradication of the grey squirrel (Sciurus carolinensis) in Italy, and consequences for the red squirrel (Sciurus vulgaris) in Eurasia. Biological Conservation 109: 351-358

Bomford M and O'Brien P (1995) Eradication or control for vertebrate pests? Wildlife Society Bulletin 23: 249-255

Burbridge AA and Morris KD (2002) Introduced mammal eradications for nature conservation on Western Australian islands: a review. In: Veitch D and Clout M (eds) Turning the Tide: the Eradication of Invasive Species, pp 64-70. IUCN SSC Invasive Species Specialist Group. IUCN, Gland, Switzerland/Cambridge, UK, viii +414 pp

Davis JR and Garcia R (1989) Malaria mosquito in Brazil. In: Dahlsten DL and Garcia JR (eds) Eradication of Exotic Pests, pp 274-283. Yale University press, New Haven,Connecticut

Galil BS (2002) Between serendipity and futility: control and eradication of aquatic invaders. Ballast Water News 11: $10-12$

Genovesi P (2000) Guidelines for Eradication of Terrestrial Vertebrates: a European Contribution to the Invasive Alien Species Issue. Council of Europe, Strasbourg, tpvs65e-2000, $61 \mathrm{pp}$

Genovesi P and Bertolino S (2001) Human dimension aspects in invasive alien species issues: the case of the failure of the grey squirrel eradication project in Italy. In: McNeely JA (ed) The Great Reshuffling: Human Dimensions of Invasive Alien Species, pp 113-119. IUCN, Gland, Switzerland/ Cambridge, UK, vi $+242 \mathrm{pp}$

Genovesi P and Shine C (2003) European Strategy on Invasive Alien Species. Council of Europe, Strasbourg, t-pvs(2003)7 rev, $50 \mathrm{pp}$
Gosling LM and Baker SJ (1989) The eradication of muskrats and coypus from Britain. Biological Journal of the Linnean Society 38 : $39-51$

Hammond MER and Cooper A (2002) Spartina anglica eradication and inter-tidal recovery in Northern Ireland estuaries. In: Veitch D and Clout $\mathrm{M}$ (eds) Turning the Tide: the Eradication of Invasive Species, pp 124-131. IUCN SSC Invasive Species Specialist Group. IUCN, Gland, Switzerland/Cambridge, UK, viii +414 pp

Hughes B, Criado J, Delany S, Gallo-Orsi U, Green AJ, Grussu M, Perennou C and Torrel JA (1999) The status of the Ruddy duck (Oxyura jamaicensis) in the western Paleartic and an action plan for eradication, 1999-2002. Report by the Wildfowl and Wetlands Trust to the Council of Europe

Jimenez J (1994) Gestione della fauna nelle piccole isole. In: Monbailliu X and Torne A (eds) La gestione degli ambienti costieri e insulari del Mediterraneo, pp 245-274. Medmaravis

Kerbiriou C, Pascal M, Le viol I and Garoche J (2004) Conséquences sur l'avifaune terrestre de lîle de Trielen (Réserve Naturelle d'Iroise, Bretagne) de l'éradication du rat surmulot (Rattus norvegicus). Revue d'Ecologie (Terre Vie) 59: 319-329

Macdonald D, Sidorovich VE, Maran T and Kruuk H (2002) European Mink, Mustela lutreola: analyses for conservation. Wildlife Conservation Research Unit, Oxford, UK, $122 \mathrm{pp}$

Martín A (2002) Rabbit Eradication on Montaña Clara (Canary Islands, Spain). Proceedings of the Workshop on Invasive Alien Species on European Islands and Evolutionary Isolated Ecosystems and Group of Experts on Invasive Alien Species (Horta, Azores). Council of Europe, Strasbourg, tpvs/IAS (2002)2, pp 14-15

Martin JL, Thibault JC and Bretagnolle V (2000) Black rats, island characteristics and colonial nesting birds in the mediterranean: consequences of an ancient introduction. Conservation Biology 14: 1452-1466

Meinesz A (1999) Killer Algae, University of Chicago Press, $376 \mathrm{pp}$

Oliveira PJ (1999) Habitat restoration on Deserta Grande, Madeira (Portugal): eradication of non-native mammals. In: Proceedings of the Workshop on the Control and Eradication of Non-Native Terrestrial Vertebrates, pp 41-42. CE, Environmental Encounters, No. 41, Council of Europe, Strasbourg, $147 \mathrm{pp}$

Orueta JF and Ramos YA (1998) Methods to Control and Eradicate Non Native Terrestrial Vertebrate Species. Nature and Environment (Council of Europe) No. 118, Council of Europe, Strasbourg, $66 \mathrm{pp}$

Pascal M (1999) Eradication of mammals introduced in the islands. In: Proceedings of the Workshop on the Control and Eradication of Non-Native Terrestrial Vertebrates, pp 31-42. CE, Environmental Encounters, No. 41, Council of Europe, Strasbourg, $147 \mathrm{pp}$

Perfetti A and Sposimo P (2001) Relazione su possibili effetti indesiderati causati dalle operazioni di eradicazione dei ratti (Rattus rattus) dell'Isolotto della Scola (LI). Report attached to LIFE-Nature LIFE97NAT/IT/4153 XII.2001 
Perfetti A, Sposimo P and Baccetti N (2001) Il controllo dei ratti per la conservazione degli uccelli marini nidificanti nelle isole italiane e mediterranee. Avocetta 25: 126

Pitta Groz M (2002) Invasive alien species as the main threat to Azores seabirds populations. In: Proceedings of the Workshop on Invasive Alien Species on European Islands and Evolutionary Isolated Ecosystems and Group of Experts on Invasive Alien Species (Horta, Azores). Council of Europe, Strasbourg, tpvs/IAS (2002)2, pp 7-8

Rejmanek M and Pitcairn J (2002) When is eradication of exotic pest plants a realistic goal? In: Veitch D and Clout $\mathrm{M}$ (eds) Turning the Tide: the Eradication of Invasive Species, pp 249-253. IUCN SSC Invasive Species Specialist Group. IUCN, Gland, Switzerland/Cambridge, UK, viii + 414 pp Rouland P (1985) Les castors canadiens de la Puisaye. Bulletin Mensuel de l'Office National de la Chasse 91: 35-40

Simberloff D (2002) Today Tiritiri Matangi, tomorrow the world! Are we aiming too low in invasives control? In: Veitch D and Clout M (eds) Turning the Tide: the Eradi- cation of Invasive Species, pp 4-12. IUCN SSC Invasive Species Specialist Group. IUCN, Gland, Switzerland/Cambridge, UK, viii +414 pp

Smallshire D and Davey JW (1989) Feral Himalayan Porcupines in Devon. Nature in Devon (Journal of the Devon Wildlife Trust) 10: 62-69

Tershy BR, Donlan CJ, Keitt BS, Croll DA, Sanchez JA, Wood B, Hermosillo MA, Howald GR and Biavaschi N (2002) Island conservation in north-west Mexico: a conservation model integrating research, education and exotic mammal eradication. In: Veitch D and Clout $M$ (eds) Turning the Tide: the Eradication of Invasive Species, pp 293-300. IUCN SSC Invasive Species Specialist Group. IUCN, Gland, Switzerland/Cambridge, UK, viii + 414 pp Wittenberg R and Cock M (2001) Invasive Alien Species: a Toolkit of Best Prevention and Management Practices. GISP/CAB International, Wallingford, UK

Zonfrillo B (2002) Puffins return to Ailsa Craig. Scottish Bird News 66: 1-2 